\title{
Childcare And Entrepreneurship: A Business Case Study
}

Stephanie Owings-Edwards, Fort Lewis College, USA Paul Herz, Fort Lewis College, USA

\begin{abstract}
The Riverhouse Children's Center is an actual day care business. The case is an example of a small niche-business common to locales across the United States. Riverhouse is atypical of private day care centers in that it is organized as a not-for-profit institution. The case reviews the benefits and pitfalls of obtaining not-for-profit tax status for a business. The case also presents the different pricing mechanisms embedded in the fee structure of the center. Case discussion questions lead students to suggest a restructuring of the revenue side of the business. Additionally, the case reveals that there may be non-monetary motivations for entrepreneurs and highlights the challenge of working within a tight budget.
\end{abstract}

Keywords: Entrepreneurship; Pricing Strategies; Non-profits

\section{INTRODUCTION}

indsay Sherman opened The Riverhouse Children's Center in May of 2003. It is a childcare and preschool
facility providing services for families with children from six weeks to five years old. Initially, the center
was licensed to care for 12 children. This grew to 22, then 35, and today the Center cares for 45 children per day.

The Riverhouse Children's Center is located in Durango, Colorado. This is a geographically isolated town of approximately 15,000 people located in a county of about 45,000 people. In a town of this size, reputation is important; mothers talk. When women get pregnant, the word from their friends is to get their child on the wait-list at Riverhouse.

Lindsay serves as the director of the facility. She has passionate opinions about what is good for children. As we shall see, she takes home less income than she could because she runs a center based on her principles. A review of the handbook she gives to parents reveals some of her priorities. She believes in the importance of good nutrition and the value of outdoor play. The children are served a varied diet which is low in refined sugar and emphasizes organic food. As long as weather permits, the children play outside in fenced, safe areas every day. Parents are asked to provide clothing (snowsuits, raingear, swim shoes) that coaxes the maximum possible cooperation from the weather. The classrooms are full of books, puzzles, blocks, and crayons. The parent handbook specifically states, "We will not watch TV or videos at school, unless there is a very special reason... The occasion would have to be soooo special that I can't think of one."

Generally speaking, the atmosphere at Riverhouse is informal yet professional. Parents sign their children in and out rather than punching a time-clock. This is typical of the informal, trust-based environment that she has established.

Families of younger children receive a hand-written note every day detailing what their child did, what the child ate and drank, and how much the child slept. The staff will often provide additional verbal information about a child's day and general developmental progress. There is a sense that the staff cares about each child and wants him/her to be as happy as possible. It feels as if it is not entirely an impersonal business transaction. Establishing 
personal bonds like these is, of course, good for business. Parents will be less price sensitive, less likely to look for replacement care, if they have a good personal relationship with their child's care givers.

Children are grouped into different classes roughly according to age:

- Infants: six-weeks to one-year

- Toddlers: one-year to two-years

- "Caterpillars": two-years to three-years

- $\quad$ "Butterflies"' three-years to four years

- $\quad$ Preschool children: four-years to five-years

State law defines the maximum number of children an adult supervisor can look after. Up until 3 years of age, in a non-home based childcare facility, there must be one adult for every 5 children. In the three-four year age bracket there must be one adult for every 10 children and in the four-five year age bracket there must be one adult for every twelve children. These ratios largely determine both the costs of running a day care center and the revenue a center can generate. State law also determines the maximum number of children per square foot of space that is allowed. This determines the minimum acceptable size of a facility.

Initially, The Riverhouse Children's Center was incorporated as a for-profit entity. However, in October 2004 Lindsay chose to officially change the Center's status to not-for-profit: 501(c)(3). The details and advantages of this change are reviewed later in this case study.

\section{REVENUE}

In 2005 Lindsay reported \$260,233 in revenue from the Riverhouse Children's Center. Ninety-eight percent of this came from fees paid by families. Thus, the fee structure of her childcare program is tremendously important.

Demand for services that Riverhouse Children's Center provides is high. Generally speaking, each class size is close to the maximum capacity allowed by law. Table 1 shows, by age category, the current adult-to-child ratios at Riverhouse and the legal limits established by Colorado law.

Table 1 Adult-to-Child Ratios

\begin{tabular}{|c|c|c|}
\hline Age Category & Riverhouse adult-to-child ratio & $\begin{array}{c}\text { Colorado legal limit, adult-to-child } \\
\text { ratio }\end{array}$ \\
\hline Infants & Two adults to eight children & $2: 10$ \\
\hline Toddlers & Two adults to ten children & $2: 10$ \\
\hline "Caterpillars" & One adult to seven children & $1: 7$ \\
\hline "Butterflies" & One adult to eight children & $1: 10$ \\
\hline Pre-school & One adult to ten children & $1: 12$ \\
\hline
\end{tabular}

In those classes which are full, Lindsay runs a wait-list. She has very egalitarian principles which are reflected in the structure of her wait-list; children are admitted on a first-come first-served basis. That is, she keeps track of the date when a child was placed on her wait-list. The family which has been waiting the longest will be the first family offered a spot when an opening arises. She has always had wait-list for at least some age categories.

Lindsay offers parents part-time schedules. As a result, although she is currently serving 43 "full-time equivalent" children, she actually sees between 55 and 60 children per week. For instance, one family may only need toddler care on Monday, Wednesdays and Fridays. Another may only need care on Tuesdays and Thursdays. Those two children, together, constitute one full-time equivalent child. A full-time child is slightly cheaper to care for than a full-time equivalent child. For the two children mentioned above, accommodated on a part-time schedule, Lindsay must bill and collect from two families rather than one, newsletters and information sheets must go to two families rather than one, space must be found for two sets of diapers rather than one, files must be kept on two children rather than one. 
Lindsay realizes that offering part-time care makes it more difficult to utilize her facilities and staff to their capacity. She has considered a fee-structure which is higher for part-time care than for full-time care. However, she is concerned that such a plan would encourage "families to bring a child an extra day even if they don't need it, and I don't believe children NEED to be here full time. Three to four days per week for parents who work part-time shouldn't be discouraged."

The flat tuition rates at Riverhouse Children's Center are as follows:

$\begin{array}{ll}\text { - } & \text { Infants: } \$ 34 / \text { day (7:45 A.M. - 4:00 P.M.) } \\ \text { - } & \text { Toddlers: \$28/day (9:00 A.M. - 3:30 P.M.) } \\ \text { - } & \text { "Caterpillars": \$26/day (9:00 A.M. - 3:30 P.M.) } \\ \text { - } & \text { Preschool children: \$23/day (9:00 A.M. - 3:30 P.M.) }\end{array}$

She established these rates to generate the revenue necessary to cover anticipated monthly expenses (payroll, rent, etc.). Unexpected, irregular, expenses must be paid for with revenue from other sources.

Hours before and after the stated times are billed at $\$ 2$ per hour. Lindsay says she has structured her daycare fees to encourage parents to spend more time with their kids. If she charged a flat rate for ten hours of day care, then more parents would choose to leave their kids for the full ten hours. "The extra hours rate is to encourage parents to pick up their children at the end of their work day...It's more of a values issue for me...children learn a lot at the grocery store and running errands - they shouldn't consistently be here for extended hours if it's not necessary."

Riverhouse has had on-going problems with late and unpaid tuition. As a result, a late-fee has been instituted: "Any tuition balance not paid in full by the $10^{\text {th }}$ of the month will incur a $\$ 10$ late charge. Every day thereafter until the balance is paid in full there will be an additional $\$ 5$ charge."

Riverhouse also charges a $\$ 30$ per family registration fee. This is paid once per year. The funds generated by this fee $(\$ 1,470)$ offset the costs of goods, such as bedding, which need to be replenished on a regular basis. The fee is assessed at the beginning of the summer. This provides a small financial incentive for families to remain with the program through the course of the year rather than simply using Riverhouse for summer coverage and then switching to a different provider in the fall.

\section{COSTS}

Staff ratios and facility size are the primary determinants of cost for a child care center.

The facility in which Riverhouse operates was previously used as a bed and breakfast. Lindsay rents this space at an annual cost of $\$ 50,456$. When she alters the facility to better suit her needs she, not the landlord, pays for the changes. In 2005 building maintenance and improvements cost her an additional $\$ 3,021$. Annual utilities totaled $\$ 4,919$. Her total occupancy costs were, therefore, $\$ 58,396$.

Her largest expenses, though, are payroll-related. Lindsay does not pay her staff excessively. ${ }^{1}$ We know this because it takes her a significant amount of time and advertising to find a qualified staff member. Recently, a worker quit to become a waitress, explaining she could make the same salary as a waitress working only three nights per week, rather than the five days she worked at Riverhouse. Yet, Lindsay spent $\$ 162,236$ on wages for her staff in 2005 . Her payroll taxes totaled another $\$ 3,769$. She also spent $\$ 4,884$ on staff and professional development that included conferences and professional meetings. This totaled $\$ 170,849$. Her own salary of $\$ 26,323$ increased payroll expenses to $\$ 197,172$ for 2005 .

\footnotetext{
${ }^{1}$ The childcare profession simply does not pay well. In 2004 the Center for the Childcare Workforce reported that "only 18 occupations out of 770 surveyed by the BLS reported having lower mean wages than child care workers. Those who earned higher wages included service station attendants, bicycle repairers and locker room attendants."
} 
Insurance costs were non-negligible. She purchases liability insurance at an annual rate of $\$ 4,699$. She also is required by the state of Colorado to purchase workers' compensation insurance through a private agency. This costs $\$ 2,469$ per year. Insurance costs total $\$ 7,168$.

\section{THE BOTTOM LINE}

It costs Lindsay $\$ 262,736$ simply to rent the facility, pay her staff and cover taxes and insurance costs. Supplies (food, toys) cost $\$ 17,044$. There are other "incidental" costs involved in running a business as well: she must have a phone, she needs to advertise for new hires, provide them with an employee handbook and run a background check on them. Altogether, these totaled another $\$ 7,759$. According to the tax return filed by The Riverhouse Children's Center in 2005 her expenses, including her salary, totaled \$287,539. However, in 2005 Lindsay collected only $\$ 267,196$ in tuition. Without donations and grants of $\$ 26,646$, about the same amount of her salary, Lindsay would essentially be running Riverhouse for a preposterous salary of about $\$ 6,000$ per year.

\section{TAX-EXEMPT STATUS}

IRS Publication 557 (Tax Exempt Status for Your Organization) indicates in its text (page 22) and in its Organization Reference Chart (page 61) that children's day-care centers may qualify for tax-exempt status. In order to be recognized as a tax-exempt organization, a children's day care center must complete and file IRS form 1023 (Application for Recognition of Exemption Under Section 501(c)(3) of the Internal Revenue Code).

When converting to tax exempt status there are two important restrictions to keep in mind. The IRS states that "upon dissolution of your organization, your remaining assets must be used exclusively for exempt purposes." Thus, if Lindsay were to wish to exit from the child care business she would have to sell the center to someone else who would maintain its tax-exempt status or she would have to sell her assets (cribs, toys, furnishings, etc.) to another tax-exempt day care provider.

Both Form 1023 (used to apply for tax-exempt status) and Form 990 (the income tax form used by taxexempt organizations), require you to list the names and titles of the five highest paid employees who receive compensation of more than $\$ 50,000$ per year. Thus, Lindsay can pay herself a salary of up to $\$ 50,000$ without having to justify it to the IRS. If she wishes to pay herself more (and has the funds to do so), she would have to justify this higher salary by comparing her compensation to "similarly situated taxable or tax-exempt organizations" (part V, Form 1023). That is, she would have to show that child care directors with duties similar to hers, who run centers similar in size to hers, earn what she is paying herself. This would be difficult to do. According to the U.S. Department of Labor's Bureau of Labor Statistics in May of 2005, educational administrators of preschool and child care centers earned an average wage of $\$ 42,670$. Moreover, seventy-five percent of all educational administrators of preschool and child care centers earn $\$ 50,660$ or less.

2005 was the first full year that Riverhouse operated as a 501(c)(3). Organizing as a 501(c)(3) allows a corporation to accept tax-deductible contributions. Prior to organizing as a 501(c)(3), Riverhouse received no cash donations. In 2005, Riverhouse received \$22,021 in cash grants and donations. Non-cash donations, in the form of art and other supplies and food, were valued at $\$ 4,625$. Cash donations were the result of several government and private agency grants, donated funds to cover the tuition of needy families, and fundraising efforts in the form of a silent auction and other fundraising activities. The value of donated goods are also included under cash donations.

Organizing as a 501(c)(3) also allows a child care center to apply for grant funding. However, Lindsay has found that some grants are very time consuming to administer and require lengthy reports. For instance, Riverhouse contracted with the Child and Adult Care Food Program (CACFP) for only six months in 2005. The guidelines of the program would not allow water to be served with meals. Protein was not a breakfast component but grain and fruit were required. Good nutrition for the children is a fundamental concern for Lindsay and she considers these restrictions to be unhealthy. She is also opposed to waste. The guidelines of the program required that each child be served their allotted amount of milk in their individual cup. If the child did not drink that full allotment at that meal then what remained had to be thrown away. 


\section{CREATIVE SUPPLEMENTS TO THE BOTTOM LINE}

Lindsay does her own payroll rather than contracting out to an accounting service. This involves much more than just writing payroll checks for her employees. She must determine how much to withhold from each employee's earnings for state and federal income taxes, Social Security, and Medicare taxes. She must pay a matching amount of Social Security and Medicare taxes on behalf of her employees. She must also pay SUTA (state unemployment tax). The federal payroll tax guidelines are described in a 68-page IRS document (Publication 15, Circular E, Employer's Tax Guide). Doing payroll is complex and detailed work. If you do it wrong there will be penalties to pay to the IRS and the state taxing authorities. As a result, many business owners choose to contract out payroll duties. However, it saves money to master the material and do it yourself.

Initially, Lindsay used the Riverhouse facility for both business purposes and residential purposes. She and her family lived in the basement for the first year and a half that Riverhouse was in operation. However, she found this was like working twenty-four hours a day, seven days a week, every week of the year. In addition, like most basements, it felt like being confined to a dungeon. She has continued to use the basement to minimize costs, offering it as a non-wage benefit to a staff member. Note that the market value of this rent must be reported to the IRS as additional wages for the staff member.

Lindsay actively uses her family to fill-in for absent staff when needed. Her mother, sister, and mother-inlaw all participate on an as-needed basis. Lindsay herself is the first choice to fill-in for absent staff. Finding temporary replacement staff for a sick or absent worker is difficult. Having trained family willing to help out is a tremendous asset.

\section{CONCLUSION}

The Riverhouse Children's Center is a "tightly run ship." There is very little waste or money devoted to superfluous purchases. It would be difficult to suggest changes which would result in significant cost savings. However, some changes could be made to the fee structure to increase revenue. Currently, what allows Lindsay to pay herself more than $\$ 6,000$ per year is the tax-exempt status of the program. Although achieving 501(c)(3) status is not easy; it is, according to Lindsay, a simpler process than obtaining a license to operate a day care center. If you are currently running a private children's day care facility, you might consider applying for tax-exempt status.

\section{AUTHOR INFORMATION}

Paul Herz is Professor of Accounting at Fort Lewis College in Durango, Colorado. He received his Ph.D. from the University of Utah. He has over 25 years of teaching experience, primarily in the areas of Financial Accounting and Auditing. He worked professionally for the former Coopers \& Lybrand and as a sole practitioner, specializing in emerging business services. Dr. Herz spent an academic year teaching as a Fulbright Scholar in Saratov, Russia. Since then he has published several articles addressing barter and taxation in Russia and international financial reporting.

Stephanie Owings-Edwards is Associate Professor of Economics at Fort Lewis College in Durango, Colorado. She received her Ph.D. from George Mason University. 


\section{TEACHING NOTES}

\section{Suggestions for Classroom Use}

This case is intended for use in small business and entrepreneurship classes. It also could be employed in a non-profit accounting class or a general accounting class which studies non-profit accounting. In addition, an early education class that considers the business aspects of running a day-care center would benefit from reviewing this case.

\section{Teaching Objectives}

1. The student shall recognize that profit maximization is not always the exclusive, or even primary, goal of an entrepreneur.

2. The student shall calculate the dollar value of tax-exempt status to the head of the organization

3. The student shall become familiar with the conditions under which entities that have tax-exempt status operate

4. The student will analyze the price structure of this organization and determine whether it is congruent with the stated goals of its leader.

5. The student will consider the scheduling problems faced by this organization and determine if a superior system could be created.

\section{Discussion Questions and Answers:}

Question 1: What are the mission and objectives for the Riverhouse Children's Center? How does the profit motive fit into Lindsey's approach to operating her business? If you were the director of the Center, would you change the mission and objectives? Do you think most entrepreneurs begin businesses strictly to make money?

\section{Answer/Discussion for Question 1:}

The intent of this question, and the case, is to point out that businesses are not exclusively profit maximizers. Lindsey is passionate about providing high quality child care. Generally, entrepreneurs see opportunities to fill needs and niches that are not properly served. Their primary goal is to successfully fill such needs and niches, with profit following. Many small businesses are a labor of love. They operate under the belief that if you do what you love the money will follow.

Question 2: Calculate the financial gains to Lindsay from organizing as a tax-exempt organization.

Answer/Discussion for Question 2:

Using numbers from the narrative, a profit and loss statement for the Center might look like the following:

\section{Revenues}

Service revenue: $\$ 260,223$ (98\% from families); annual fees @ $\$ 30=\$ 1,470$; government contracted services, $\$ 5,503$ $\$ 267,196$

Donations

26,646

Total revenues

$\$ 293,842$ 


\section{Expenses}

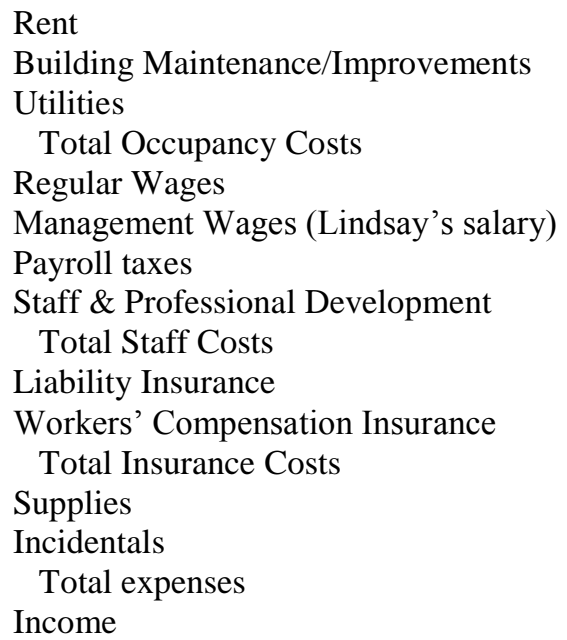

$\$ 50,456$

$\$ 3,021$

$\$ 4,919$

$\$ 162,236$

$\$ 26,323$

$\$ 3,769$

$\$ 4,919$

$\$ 4,699$

$\$ 2,469$
$\$ 58,396$

$\$ 197,172$

$\$ 7,168$

$\$ 14,000$

$\$ 7,759$

$\$ 287,539$

$\$ 6,303$

Tax-exempt status enabled the Center to raise donations of $\$ 26,646$. While these donations did not directly fund additional salary for Lindsay, they offset other expenses of the center normally paid directly from day care revenues. The result, indirectly, was a salary of $\$ 26,323$ for Lindsay.

Question 3: What characteristics determine whether a business would benefit from tax-exempt status? Would Riverhouse's status as a tax-exempt organization impact any future decisions as to whether to purchase the building that currently houses the child-care facility?

\section{Answer/Discussion for Question 3:}

Businesses that produce a product or a service that engenders donations will benefit from organizing as a tax-exempt entity. If others are willing to donate to you, organizing as anything other than a tax-exempt entity is essentially leaving money on the table. Likewise, if there are grants available to non-profits in this field, then organizing as a tax-exempt institution can be a wise investment.

Any business that requires the purchase of significant durable assets that have uses outside of the non-profit arena should think very carefully before converting to tax exempt status. When a tax-exempt organization is dissolved, its residual assets must remain in the tax-exempt sector; they cannot be sold to a for-profit business. If an organization primarily uses consumable goods, this restriction does not pose a big problem; there will be few to no residual assets. If the organization uses durable assets that have no use outside of the not-for-profit sector, this restriction does not pose a problem. However, if the organization uses durable assets that can be sold to businesses in the for-profit sector, organizing as a tax-exempt organization will limit the resale market for those goods. For Riverhouse, most of their assets are consumable goods (cribs, toys, highchairs all wear out readily). Therefore, organizing as a not-for-profit entity is not significantly restricting.

If The Riverhouse Children's Center purchased the building that currently houses the child-care facility, upon dissolution of The Riverhouse Children's Center, that building would have to be resold to another tax-exempt entity. That is, Lindsay would have to find someone who wanted to run a not-for-profit organization from that building. This significantly restricts her resale options. Even if the facility were to continue to be used as a childcare center, she would need to locate a purchaser who wanted to run a not-for-profit daycare. Recall that the building housed a for-profit bed and breakfast prior to its current use. If the building becomes available for purchase and Lindsay believes it is cost effective to buy it, she would be well-advised to purchase it personally and then have The Riverhouse Children's Center lease it from herself. 
Question 4: The case states "some changes could be made to the fee structure to increase revenue." In seeking to determine how the fee structure could be changed, contrast the flat rate fees, on an hourly basis, with the extended hours rate. What factors should be considered when determining whether to increase the extended hours rate? Is the current fee structure consistent with Lindsay's expressed ideology?

\section{Answer/Discussion for Question 4:}

Lindsay sets her extended hours rate at $\$ 2 /$ hour. This is, in fact, lower than the flat hourly rate:

- $\quad$ Toddlers flat rate $=\$ 4.31 /$ hour

- $\quad$ Caterpillars flat rate $=\$ 4.00 /$ hour

- $\quad$ Butterflies and preschoolers flat rate $=\$ 3.54 /$ hour

Although one of her stated goals is to encourage parents to pick-up their kids immediately after work rather than running errands first, these reduced rates may, in fact, encourage parents to do the opposite. After all, an extra hour of care is just two bucks! This is care offered at an approximate 50\% discount to the regular rate.

When considering whether to increase the extended hours rate, Lindsay should reflect on what rate she should charge. Two obvious possible choices are: (1) the same hourly rate she charges as a flat fee or (2) a higher rate, say, $\$ 6 /$ hour for every extra hour. As an initial increase, route (1) is easy to justify; the new extended rate is now set at the same level as the flat rate. Obviously, the higher the rate the more likely parents are to choose to pick up their kids first and then run errands.

As her extended hours rates increase there should be fewer families who make use of them. If her extended hours rate increased to $\$ 4 /$ hour, she could lose approximately $50 \%$ of her after hours enrollment and still break-even in terms of revenue. How much demand for after-hours care will drop will depend on how many parents have flexibility in their child-care needs. Those who are using the extra hours to run errands may well choose to pick their kids up earlier. Those who are faced with work schedules that are not flexible will continue to purchase the extra hours of care. This latter group, when faced with a higher total child care bill, may begin to look around for other child care options. How many of these families she will eventually lose depends on:

- $\quad$ Prices charged by her competitors

- $\quad$ Availability of competitors

- $\quad$ Quality of competitors

Recall that Riverhouse has always maintained wait-lists. Thus, it appears that demand for the services provided by Riverhouse are quite high. Families that she loses have replacements waiting.

Having fewer children remain for extended-hours care will affect her staffing needs. Assume a 50\% increase in extended-hours rates leads to a less than $50 \%$ decrease in extended hours children. This extra revenue could be used to pay her staff higher hourly rates. She may find that demand for extended hours care drops to the point that she can reduce her extended hours staff. So, some staff might see an increase in their hourly rate but a decrease in the number of hours that they work. Whether this is regarded favorably by her employees depends on how they value their leisure time relative to a pay-check of a certain size.

Question 5: Lindsay currently charges the same flat rate to part-time families (those who use her facility less than five days per week) and full-time families. Part-time children make it more difficult for her to utilize her staff and facilities to their capacity. They are also slightly more costly to service. How much revenue is Lindsay foregoing because she is not at her legal limit for the maximum number of children in each class? Although she has considered charging a higher rate to part-time families, she does not want to establish a fee structure that would "encourage families to bring a child an extra day if they don't need it." Suggest a two-tier fee system where part-time families would pay a higher rate but which would incorporate monetary incentives for those who worked part-time to use day-care on a part-time basis. 
Answer/Discussion for Question 5:

Revenue she is foregoing because she is not at her legal limit for the maximum number of children in each class:

Infants: short two children: $2(\$ 34)(5$ days per week $)(50$ weeks per year $)=\$ 17,000$

Butterflies: short two children: $2(\$ 23)(5$ days per week $)(50$ weeks per year $)=\$ 11,500$

Preschoolers: short two children: $2(\$ 23)(5$ days per week $)(50$ weeks per year $)=\$ 11,500$

TOTAL $=\$ 40,000=$ revenue shortfall resulting from not fully utilizing the teachers she is paying

Recall that Lindsay, as the operator of a non-profit, is allowed by law to take home $\$ 50,000$. However, she only is taking home $\$ 26,323$. The difference could be made up by running closer to capacity.

\section{Possible Two-tier Fee System}

A family whose toddler attends 5 days per week currently pays $\$ 140$ per week ( $\$ 28 /$ day). A family whose toddler attends 4 days per week would be indifferent between a four day a week schedule and a 5 day per week schedule if part-time rates were raised to $\$ 35$ per day $(4 \times \$ 35=\$ 140)$. Thus, if Lindsay set the part-time fee above $\$ 28 /$ day but below $\$ 35 /$ day, she would be able to make-up some of her lost revenue due to the scheduling problems posed by part-time service. At the same time, families with a part-time schedule should still choose to spend their free days with their children. For instance, at $\$ 30 /$ day for part-time care, a 4-day per week schedule costs $\$ 120$ while the 5-day per week schedule costs $\$ 140$. Moving tuition from $\$ 28 /$ day to $\$ 30 /$ day is a $7.1 \%$ increase. This is easy to justify in terms of the higher staffing and accommodation costs created by part-time care. 
NOTES 